\title{
Initiation of International Collaborative Study on Breast Cancer Between Japan and Indonesia
}

\author{
Yoshiyuki Ohno*
}

Our collaborative study has been officially entitled as "Japan Indonesia Joint Study on Etiology and Clinicopathology of Breast Cancer". This project has been supported by a grant from the Ministry of Education, Science and Culture of the Japanese Government (Grant No. 01042007 and 04042013).

This granting system of International collaborative study has started since 1984 as Special Cancer Research Project in Monbusho International (formerly Over-sea) Scientific Research Program in Anti-Cancer 10-year Comprehensive Strategies of the Japanese Government, the so-called Premier Nakasone Project.

Anti-Cancer 10-Year Comprehensive Strategies have initiated to cope with human enemy of cancer in Japan, and included 5 major fields of study: 1) Studies on Oncogene, 2) Studies on human cancer caused by viruses, 3) Studies on promotion and inhibition of cancer development, 4) Studies on evolution of new cancer diagnostics and therapy, and 5) Studies on immune suppression and suppression substances. Besides these 5 major studies in Japan, Special Cancer Research Project encouraged to undertake collaborative studies with foreign countries such as cancer information exchanges and basic studies on epidemiological characteristics of cancers in the world (Table 1).

When the granting started in 1984, there were 12 study projects covering 18 countries, and now in 1993, 21 study projects covering 27 countries are on-going. As one of these international collaborative studies, our study project officially started in 1989, when 17 study projects covering 15 countries were on-going.

\footnotetext{
Department of Preventive Medicine Nagoya University, School of Medicine, 65 Tsurumai-cho, Showa-ku, Nagoya 466, Japan.

Coordinator of the Japanese team, Japan-Indonesia Joint Study on Etiology and Clinicopathology of Breast Cancer.
}

Table 1. Studies Covered by Special Cancer Research Project in Monbusho International Scientific Research Program in 10 Years (1984-1993)

1. Exchanges of scientific information on cancer researches in advanced countries (with United States, Canada, Germany, France, other European countries)

2. Viruses related to carcinogenesis and parasites

ATL/HAM (HTVL-1), Hepatitis virus (HBV, HCV), Human Papiloma Virus (HPV)

Mice Leukemia Virus, Opisthorchis Veverrini

3. Promoting/anti-cancer agents existing in the natural enviroment.

Natural plants (in Thailand, USA, Brazil, African countries such as Tanzania)

Marine organism (in Australia)

4. Migration studies on cancer

Korean in Osaka, Japanese Americans in Los Angeles, Japanese descendants in Brazil and Bolivia

5. Studies on very common or rare cancers

Stomach, Colon, Liver, Bile duct, Lung, Nasopharinx, Breast, Cervix uteri.

Skin (xeroderma pigmentosa), Neuroblastoma, Prostate, Leukemia, Lymphoma, etc).

6. Studies on cancer diagnostics and therapy

Monoclonal antibody, Chemotherapy, hyperthermia, etc.

Table 2. Chronological Development of Special Cancer Research Projects in Monbusho International Scientific Program in 10 Years (9184-1993)

\begin{tabular}{lcc}
\hline $\begin{array}{l}\text { Fiscal } \\
\text { year }\end{array}$ & $\begin{array}{c}\text { Projects } \\
(\text { No. })\end{array}$ & $\begin{array}{c}\text { Countries collaborated } \\
\text { (No.) }\end{array}$ \\
\hline 1984 & 12 & 18 \\
1985 & 13 & 25 \\
1986 & 14 & 25 \\
1987 & 15 & 20 \\
1988 & 16 & 20 \\
1989 & 17 & 15 \\
1990 & 18 & 20 \\
1991 & 20 & 23 \\
1992 & 22 & 27 \\
1993 & 21 & 27 \\
\hline Net total & 50 & 55 \\
\hline
\end{tabular}


Table 3. Countries collaborated in Special Cancer Research Projec ts in Monbusho International Scientific Re-. search Program in 10 Years (1984-1993).

\begin{tabular}{|c|c|c|}
\hline Region & Countries & No. \\
\hline Asia, China, & $\begin{array}{l}\text { South Korea, Mongolia, HongKong } \\
\text { Philipines, Taiwan, Thailand, Malaysia } \\
\text { Indonesia, Singapore, Myanmar, Pakistan } \\
\text { India, Sri Lanka, Bangladesh }\end{array}$ & 15 \\
\hline $\begin{array}{l}\text { Africa \& } \\
\text { Middle East }\end{array}$ & $\begin{array}{l}\text { Ghana, Gabon, Kenya, Tanzania, Zaire, } \\
\text { Liberia, Tunisia, South Africa, } \\
\text { Madagaskar, Cameroon, Chad, Ethiopia, } \\
\text { Uganda, Somalia, North Yemen }\end{array}$ & 15 \\
\hline Oceania & $\begin{array}{l}\text { French Polynesia, Australia, Papua New } \\
\text { guinea, Tonga }\end{array}$ & 4 \\
\hline North America & United States, Canada & 2 \\
\hline $\begin{array}{l}\text { Middle \& } \\
\text { South Anerica }\end{array}$ & $\begin{array}{l}\text { Columbia, Chile, Brazil, Bolivia, Peru } \\
\text { Paraguay, Jamaica, Guatemala, Costa Rica }\end{array}$ & 9 \\
\hline Europe & $\begin{array}{l}\text { U.K., Germany, France, Italy, } \\
\text { Netherlands, Switzerland, Sweden, } \\
\text { Finland, Hungary, Spain }\end{array}$ & 10 \\
\hline Total & & 55 \\
\hline
\end{tabular}

Since Special Cancer Research Project in Monbusho International Scientific Research Program usually gives 3-5 years, financial support for one project, then, as a net total, 50 study projects have been conducted in 10 years from 1984 to 1993. (Table 2 and Table 3). In the last fiscal year, 1992, there were 22 study projects covering 27 countries as listed in Table 4 .

To initiate our joint study, which officially started in 1989, we needed some preparatory period with consultation meetings.

Chronological history of initiating and developing this joint study in Indonesia is as follows.

In August, 1987, I as an epidemiologist and Dr. Sakamoto as a pathologist visited Jakarta for the first time to search for the possibility or feasibility of conducting collaborative study here in Jakarta by meeting and discussing with several key investigators in epidemiology, pathology and surgical oncology. Persons whom we actually met and talked with were Drs. Alex Papilaya, Bambang Sutrisna, Santoso Cornain, Sutisna Himawan, Gunawan Tjahjadi, and Didid Tjindarbumi.

In this meeting we discussed and overviewed in details the former study project of cervical cancer in Indonesia with constructive lessons, and after serious discussion, I and Dr. Sakamoto reached to the impression of the conclusion that collaborative epidemiological, pathological and clinical studies would probably be feasible, and an epidemiological investigation of casecontrol study would be a min study design. We selected breast cancer as a cancer site to be studied, because it is the second commonest cancer among females in Indonesia, following cervical cancer which had been already jointly studied between Japan and Indonesia in 1984-1986.

Again, in April, 1988, I and Dr. Sakamoto visited Jakarta and discussed the planning of a collaborative study between Japan and Indonesia with Drs. Santoso Cornain, Gunawan Tjahjadi, Didid Tjindarbumi, Muchlis Ramli and Joedo Prihartono.

In this meeting, we mainly discussed four major points. The first point was tentative decision of Indonesia team members and a coordinator of the team. the second point was planning of a breast cancer case control study, including very practical aspects of study design such as definition of cases and controls with inclusion and exclusion criteria, information to be collected and tentative designing of a questionnaire to be used at direct interview of the study subjects. The third point was planning of pathological and clinical studies. The fourth point was planning of inviting Indonesian researchers to Japan during the study period of 3 to 5 years. After deliberate discussions, we could reach tentative conclusions for these four points.

In September. the same year, 1988, I visited Jakarta again to finalize the study protocol and discuss budgetary aspects of the collaborative project. this was the third visit to Jakarta to ensure semi-official start of our collaboration.

In this meeting, in particular, we finally decided Indonesian team members and a coordinator. They were Dr. Santoso Cornain as a coordinator, Drs. Joedo Prihartono and Setyawati Budiningsih as epidemiologists, Drs. Didid Tjindarbumi, Muchlis Ramli and Idral Darwis as surgical oncologists and Drs. Gunawan Tjahjadi, Esti Soetrisno and Endang Sri Roostini as pathologists. (In the Extension Study of our collaborative project, we also included two nutritionists; Drs. Drupadi Dillon and Susilowati Herman).

Then we finalized all study designs of case-control study and completed the development of the questionnaire to be used at direct interview of cases and controls. The actual study design of our case-control study of breast cancer will be described in details in the following papers of this monograph.

At this stage, since we could finalize all aspects of case control study, I requested the Indonesian team mem- 
Table 4. Principal Investigators, Research Projects, and Countries Collaborated in 1992

\begin{tabular}{|c|c|c|}
\hline $\begin{array}{l}\text { Principal } \\
\text { Investigator }\end{array}$ & Research Project & $\begin{array}{l}\text { Countries } \\
\text { Collaborated }\end{array}$ \\
\hline $\begin{array}{l}\text { 1. Suketami Tominaga } \\
\text { (Aichi Cancer Center } \\
\text { Res.Inst.) }\end{array}$ & $\begin{array}{l}\text { Executive Committee of the Special Cancer Research } \\
\text { Programs; Planning, Coordination, and Evaluation }\end{array}$ & $\begin{array}{l}\text { China, Columbia } \\
\text { Guatemala, }\end{array}$ \\
\hline $\begin{array}{l}\text { 2. Hidenobu Watanabe } \\
\text { (Niigata Univ.) }\end{array}$ & Studies on biliary tract cancer in Chile & Chile \\
\hline $\begin{array}{l}\text { 3. Hiroyuki Schimizu } \\
\text { (Gifu Univ.)Los Angeles }\end{array}$ & Life-style and cancer among Japanese/Whites in Los Angeles & U.S.A. \\
\hline $\begin{array}{l}\text { 4. Yoshiyuki Ohno } \\
\text { (Nagoya Univ.) }\end{array}$ & $\begin{array}{l}\text { Japan-Indonesia joint study on etiology and } \\
\text { clinicopathology of breast cancer }\end{array}$ & Indonesia \\
\hline $\begin{array}{l}\text { 5. Ryuichiro Sasaki } \\
\text { (Aichi Med. Coll.) }\end{array}$ & $\begin{array}{l}\text { Cooperative study on breast cancer between India } \\
\text { and Japan }\end{array}$ & India \\
\hline $\begin{array}{l}\text { 6. Mitsuhiro Osame } \\
\text { (Kagoshima Univ.) }\end{array}$ & $\begin{array}{l}\text { Epidemiology and pathology of human retrovirus } \\
\text { infection }\end{array}$ & $\begin{array}{l}\text { Kenya, Ghana, Gabon, } \\
\text { Oman, India, Singapore, } \\
\text { Australia }\end{array}$ \\
\hline 7. Takao Shigematu & Study on liver cancer among Korean migrants in Japan & Korea \\
\hline $\begin{array}{l}\text { 8. Hidetoshi Ikeda } \\
\text { (Aichi Cancer Center } \\
\text { Res. Inst.) }\end{array}$ & Screening of endogenous retroviruses in Asian wild mice & $\begin{array}{l}\text { Pakistan, India } \\
\text { Bangladesh, Thailand, } \\
\text { Vietnam, Philippines, } \\
\text { Indonesia }\end{array}$ \\
\hline $\begin{array}{l}\text { 9. Kiyoshi Takatsuki } \\
\text { (Kumamoto Univ.) }\end{array}$ & Comparative study of ATL and HTLV-I related disorders & U.S.A., U.K., Brazil \\
\hline $\begin{array}{l}\text { 10. Shunro Sonoda } \\
\text { (Kagoshima Univ.) }\end{array}$ & $\begin{array}{l}\text { Virological and geno-epidemiological studies on } \\
\text { HTLV-I/II related diseases in Jamaica and Columbia }\end{array}$ & Jamaica, Columbia \\
\hline $\begin{array}{l}\text { 11. Toshio Kuroki } \\
\text { (Tokyo Univ. Inst. } \\
\text { Med.Sci.) }\end{array}$ & $\begin{array}{l}\text { Co-operative study and information exchange with European } \\
\text { countries }\end{array}$ & $\begin{array}{l}\text { France, U.K., Germany, } \\
\text { other European co. }\end{array}$ \\
\hline $\begin{array}{l}\text { 12. Nobuo Yamaguchi } \\
\text { (Tokyo Univ. Inst. } \\
\text { Med.Sci.) }\end{array}$ & $\begin{array}{l}\text { Information exchanges on cancer research with North } \\
\text { American Countries }\end{array}$ & U.S.A., Canada \\
\hline $\begin{array}{l}\text { 13. Nobuyuki Ito } \\
\text { (Nagoya City Univ.) }\end{array}$ & $\begin{array}{l}\text { Correlation between infection of Opisthorchis veverrini } \\
\text { and the development of hepatitis, liver cirrhosis and hepatic } \\
\text { neoplasias }\end{array}$ & Thailand \\
\hline $\begin{array}{l}\text { 14. Horota Fujiki } \\
\text { (Natl Cancer Center) }\end{array}$ & $\begin{array}{l}\text { Investigation of anticancer agents derived from marine } \\
\text { organisms in Australia }\end{array}$ & Australia \\
\hline $\begin{array}{l}\text { 15. Kenkichi Koiso } \\
\text { (Tsukuba Univ.) }\end{array}$ & $\begin{array}{l}\text { Japan-U.S. cooperative group study on the occurrence and } \\
\text { growth of prostatic cancer }\end{array}$ & U.S.A. \\
\hline $\begin{array}{l}\text { 16. Kenichi Kobayashi } \\
\text { (Kanazawa Univ.) }\end{array}$ & Hepatitis C Virus and hepatoma between U.S.A. and Japan & U.S.A. \\
\hline $\begin{array}{l}\text { 17. Nanao Kamata } \\
\text { (Hiroshima Univ.) }\end{array}$ & $\begin{array}{l}\text { Comparative study of cytogenetic and molecular findings } \\
\text { in lymphatic malignancies among Japan, U.S.A., China } \\
\text { India }\end{array}$ & $\begin{array}{l}\text { U.S.A., China, } \\
\text { India }\end{array}$ \\
\hline $\begin{array}{l}\text { 18. Yoichi Nakanishi } \\
\text { (Kyushu Univ.) }\end{array}$ & $\begin{array}{l}\text { Comparative study on female lung cancer in Japan, U.S.A. } \\
\text { and China }\end{array}$ & U.S.A., China \\
\hline $\begin{array}{l}\text { 19. Keiichi Kawai } \\
\text { (Kyoto Pref.Univ.) }\end{array}$ & Study on risk factors of gastro-intestinal cancer in Taiwan & Taiwan \\
\hline $\begin{array}{l}\text { 20. Tsutomu Nakanishi } \\
\text { (Setunan Univ.) }\end{array}$ & $\begin{array}{l}\text { Antitumor substance of the Muchillage-secrete plants in } \\
\text { western U.S.A. }\end{array}$ & U.S.A. \\
\hline $\begin{array}{l}\text { 21. Masamichi Kojiro } \\
\text { (Kurume Univ.) }\end{array}$ & $\begin{array}{l}\text { Comparative study on the mechanism of hepatocarcino- } \\
\text { genesis }\end{array}$ & Spain \\
\hline $\begin{array}{l}\text { 22. Shaw Watanabe } \\
\text { (Natl Cancer Center) }\end{array}$ & $\begin{array}{l}\text { Epidemiologic study for stomach cancer among Japanese } \\
\text { and non-Japanese residents in South America }\end{array}$ & Brazil \\
\hline
\end{tabular}


bers and the coordinator to undertake a pilot study of 20 cases and 40 controls, following the procedures which decided in this meeting.

As for inviting Indonesian researches, we decided to invite a pathologist for a month in November, 1988 to stay in Nagoya City University, which was my affiliation at this time, and in the Cancer Institute of Tokyo. The main purpose in inviting a pathologist was to standardize the microscopic technology of examining histopathological specimens of breast cancer between Indonesia and Japan.

We also decided to take one more step to strengthen our future collaboration of studyng breast cancer. This step was later realized to be very important and significant.

The step was for us, all Indonesian team members and I were to meet the Dean, University of Indonesia, School of Medicine to let him know in details what we planned to study with what aims and how and why we collaborate in this particular study.

Again in January, 1989, I visited Jakarta. this was the fourth visit to meet Indonesian team members and discuss the collaborative study in more details, and to evaluate the feasibility and methodological issues in the pilot study which $I$ requested to undertake in the third meeting, that is, four months earlier. Based on the results of the pilot study, we resived the questionnaire and modified the procedures of case and control selection. We attempted to readjust whole methodological procedures in the whole study planning.

As for the invitation of Indonesian researchers in the coming official study period of there years (1989 to 1991), we came to the conclusion that we would schedule to invite a surgeon in the first year, an epidemiologist in the second year, and the coordinator of the Indonesian team members in the third year. (In the period of Extension Study, we dicided to invite a surgeon in the fourth year, and a nutritionist in the fifth year).

The Indonesian team members and I again met the Dean and explained the whole process of future collaboration, and asked him to give us an approval that Indonesian researchers could join in the collaboration and have responsible roles in the whole process of the collaborative study. We also discussed and decided several other important aspects in the collaboration such as data collection and maintenance, data editing, data analysis, and publication of papers, including authorship and the general rules in ordering authors's names.

After these preparatory meetings with sincere discussions, we could successfuly start our present collaborative study on breast cancer between Japan and Indonesia.

\section{Acknowledgments}

This work was supported by the Ministry of Education and CuIture, Japan, Grants No. 01042007 and 04042013; and was partly supported by the Indonesian Cancer Foundation. This collaborative study was a part of Special Cancer Research Project in Monbusho International Scientific Research Program, with the approval of the Dean, Faculty of Medicine, University of Indonesia No. 4383 / PT02.H4.FK / E / 88. 